\title{
NUMERICKÁ ANALÝZA SPRIAHNUTIA NOSNÍKOV NA BÁZE KOMPOZITOV S BETÓNOM
}

\author{
NUMERICAL ANALYSIS OF SHEAR RESISTANCE ON COMPOSITE \\ BEAMS
}

\author{
Michala Weissová ${ }^{1}$, Vincent Kvočák ${ }^{1}$, Daniel Dubecký ${ }^{1}$, Patrícia Vaňová ${ }^{1}$
}

michala.weissova@tuke.sk,vincent.kvocak@tuke.sk, daniel.dubecky@tuke.sk

1 Ústav inžinierskeho stavitel'stva, Stevabná fakulta, Technická univerzita v Košiciach, Vysokoskolska 4, 04023 Kosice, Slovenská republika

\begin{abstract}
Abstrakt
Súčast'ou prípravy experimentálneho overovania spriahovacích prvkov je aj numerická analýza skúmaného problému. Hlavným predmetom tohto výskumu je MKP analýza vybraného experimentu, t. j. pretláčacích skúšok. Na MKP analýzu bol vybraný softvér Abaqus/CAE. Táto práca sa bude venovat' modelovaniu pretláčacej skúšky vo vybranom softvéri.
\end{abstract}

\section{Klíčová slova}

Numerická analýza, metóda konečných prvkov, prvky na báze sklených vlákien

\begin{abstract}
The part of the preparation of experimental verification of shear connectors is also a numerical analysis of the examined problem. The main subject of this research is the FEM analysis of a chosen experiment, the push out test. For FEM analysis, we have opted for Abaqus/CAE software. This piece of work will focus on the modelling of the push out test via software stated above.
\end{abstract}

Key words

Numerical analysis, finite element method, fibre reinforced polymer beams

\section{1 ÚVOD}

Na analýzu spriahnutia kompozitného nosníka s betónom bol použitý softvér Abaqus. Tento softvér je určený na analýzu metódou konečných prvkov pre počítačové inžinierstvo. Softvér ponúka spolu 5 softvérových produktov na rôzne analýzy. Prvý z nich je Abaqus/CAE (Complete Abaqus Environement), ktorý sa používa na modelovanie a analýzu mechanických komponentov a zostáv. Ďalší z nich je implicitný iteračný produkt, Abaqus/Standard, ktorý má všeobecné použitie. Na nelineárnu analýzu s množstvom vstupných informácií ako je kontakt, zat'aženie, či okrajové podmienky, slúži produkt Abaqus/Explicit, ktorý bol použitý na analýzu šmykovej odolnosti spriahnutia. Štvrtým z nich je produkt Abaqus/CFD (Computation Fluid Dynamics), ktorý slúži na analýzu dynamiky kvapalín. Posledným z nich je Abaqus/Electromagnetic slúžiaci na analýzu pokročilých výpočtových elektromagnetických úloh.

\section{PRETLÁČACIA SKÚŠKA}

Hlavným princípom pretláčacej skúšky je zistit’ šmykovú odolnost' spriahovacieho pásu. Pretláčacia vzorka je tvorená dvoma betónovými kvádrami so šírkou $200 \mathrm{~mm}$, dížkou $600 \mathrm{~mm}$ a výškou $600 \mathrm{~mm}$. Do týchto dvoch betónových kvádrov boli zabetónované spriahovacie pásy, s dížkou spriahnutia $400 \mathrm{~mm}$. Spriahovacie pásy tvoria dva nosníky vyrezané z kompozitného profilu s dížkou $600 \mathrm{~mm}$ a boli zabetónované do kvádrov tak, aby ich poloha bola $100 \mathrm{~mm}$ od spodného okraja kvádra a $100 \mathrm{~mm}$ nad horným okrajom. Aby sa zistila skutočná odolnost' spriahnutia a nosník sa nezatláčal do betónu, bol pod nosník vložený polystyrén v hrúbke $10 \mathrm{~mm}$. Nosníky boli pripevnené ku ocel'ovému profilu tak, aby bolo možné dosiahnut' posun celej strednej časti spolu s kompozitnými nosníkmi teda, bolo potrebné zabezpečit' dostatočnú tuhost' spoja. Tento spoj je štandardne realizovaný zvarom 
ale ked’že ide o skúšku spriahnutia kompozitného nosníka tak tento spoj musel byt' realizovaný skrutkami. Tým pádom, vznikla stredová čast' v celkovej dížke $600 \mathrm{~mm}$, kde ku pásniciam ocel’ového nosníka, boli pripevnené pásnice dvoch kompozitných nosníkov pomocou ocel'ových skrutiek. Ked’že by mohlo dôjst' ku nadbytočnému spriahnutiu skrutiek s betónom, tak bolo nutné plochu okolo skrutiek zabezpečit' montážnou penou. Betónové kvádre boli vystužené GFRP výstužou tak, aby výstužné prúty boli súčast'ou spriahovacieho pásu.

PÔDORYS

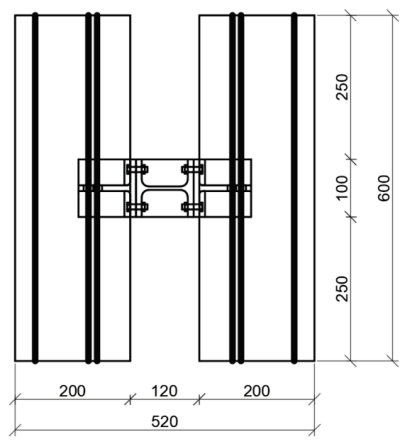

BOČNÝ POHL'AD

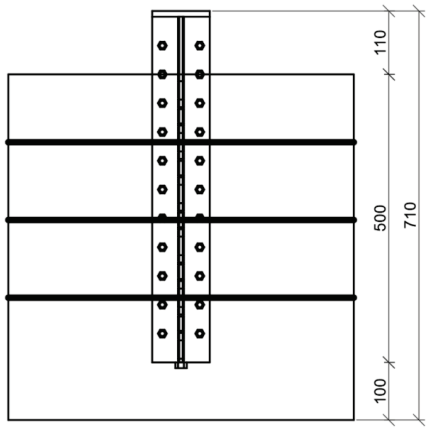

REZ

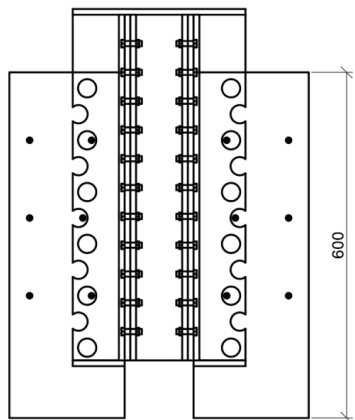

Obr. 1 Gemotria vzorky na pretláčaciu skúšku.

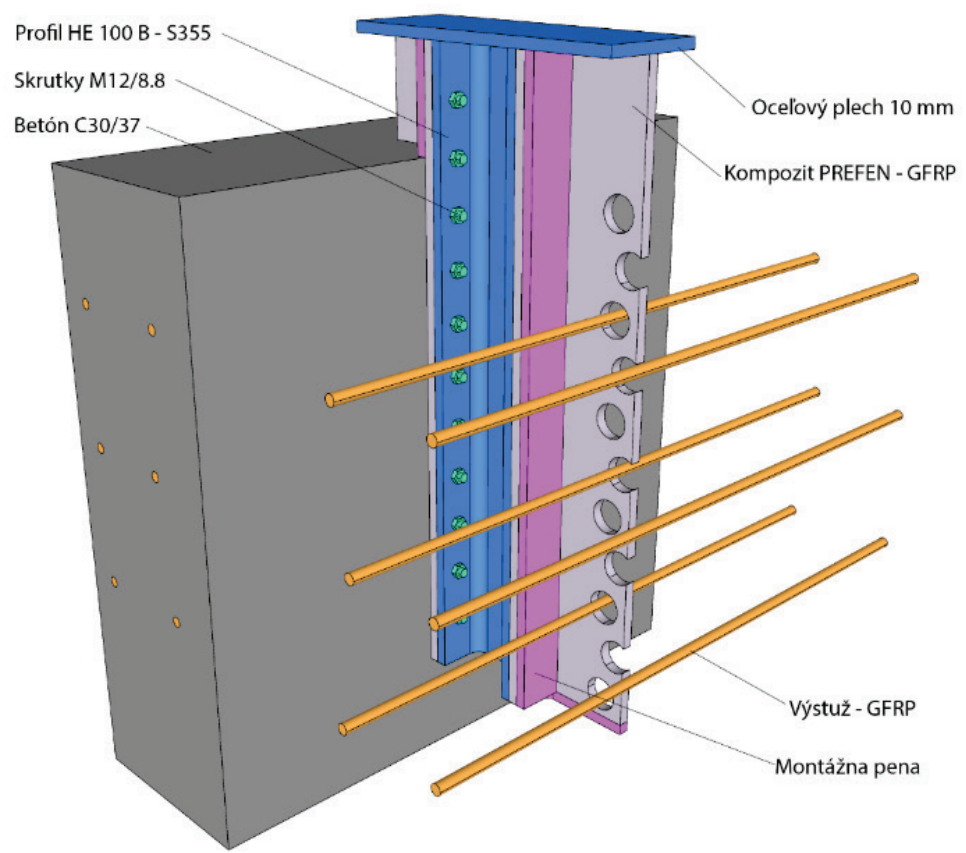

Obr. 2 Jednotlivé časti pretláčacej skúšky.

\section{PROSTREDIE MKP SOFTVÉRU}

Uvedený softvér je použitel'ný na všeobecné statické, ale aj dynamické úlohy. Rieši problém ako celok a pri správnom modelovaní dokáže upozornit’ na problémy v konštrukciách, ktoré sa približujú realite. Úlohy rieši pomocou 3D MKP analýzy, čo je na rozdiel od 2D MKP analýzy presnejšie. Jeden z hlavných vstupov potrebných na správne vystihnutie správania sa úlohy je správne a podrobné zadanie materiálových charakteristík. 


\begin{tabular}{|l|c|c|c|c|c|}
\hline Quantity & SI & SI(mm) & SI & US Unit(ft) & US Unit(inch) \\
\hline Length & $m$ & $m m$ & $m$ & $f t$ & $i n$ \\
\hline Force & $N$ & $N$ & $k N$ & $l b f$ & $l b f$ \\
\hline Mass & $k g$ & tonne $\left(10^{3} \mathrm{~kg}\right)$ & tonne & $\mathrm{slug}$ & $\mathrm{lbf} \mathrm{s}^{2} / i n$ \\
\hline Time & $\mathrm{s}$ & $\mathrm{s}$ & $\mathrm{s}$ & $\mathrm{s}$ & $\mathrm{s}$ \\
\hline Stress & $P a\left(\mathrm{~N} / \mathrm{m}^{2}\right)$ & $M P a\left(\mathrm{~N} / \mathrm{mm}^{2}\right)$ & $k P a$ & $l \mathrm{bf} / \mathrm{ft}^{2}$ & $\mathrm{ps} i\left(\mathrm{lbf} / \mathrm{in}^{2}\right)$ \\
\hline Energy & $J$ & $m J\left(10^{-3} \mathrm{~J}\right)$ & $\mathrm{KJ}$ & $\mathrm{ftlbf}$ & $i n l b f$ \\
\hline Density & $\mathrm{kg} / \mathrm{m}^{3}$ & tonne $/ \mathrm{mm}^{3}$ & tonne $/ \mathrm{m}^{3}$ & $\mathrm{slug} / \mathrm{ft}^{3}$ & $\mathrm{lbf} \mathrm{s}^{2} / \mathrm{in}^{4}$ \\
\hline
\end{tabular}

Obr. 3 Jednotky v softvéri Abaqus.

Prostredie softvéru Abaqus pracuje s modulmi, v ktorých sa postupne definujú jednotlivé vstupy na riešenie úlohy.

- Part - tento modul slúži na vytvorenie geometrie úlohy pomocou modelovania alebo importu 2D alebo 3D prvku.

- Property - modul, v ktorom sa zadefinujú jednotlivé materiálové charakteristiky, orientácia súradnicových osí v anizotropných materiáloch, či kalibrácia materiálu pomocou pracovného diagramu. V tomto module sa priradzujú materiály k prvkom vytvorených v predchádzajúcom module

- Assembly - v module part bola vytvorená geometria jednotlivých súčastí úlohy a v tomto module sú tieto časti spojené do výsledného usporiadania riešenej úlohy.

- Step - modul slúžiaci na zadefinovanie typu výpočtu, dížky výpočtu, ale aj výstupy, či počet zápisov, ktoré sú očakávané.

- Interaction - tu sa určia jednotlivé mechanické alebo termodynamické parametre kontaktov medzi dvoma plochami. Umožňuje zadefinovanie kontaktu, ktorý je dokonale tuhý, ale aj naopak kontakt medzi plochami, kde je potrebné uvažovat's trením. Definujú sa tu aj časti, ktoré nemajú tendenciu sa deformovat'.

- Load - modul, kde sa určujú okrajové podmienky celej úlohy. Dovol'uje zadefinovat' zat'aženie, uloženie, preddefinovaný posun, či rotáciu. Má vystihovat' správanie sa úlohy ako celku.,

- Job - v tomto module sa spúšt’a výpočet, pričom je možné výpočet sledovat'.

- Visualization - grafický modul, kde sa väčšinou graficky zobrazujú výsledky ako napätia, posuny, deformácie, poškodenia.

- $\quad$ Sketch - modul slúžiaci na zadefinovanie 2D aj 3D geometrie.

\section{MODUL PART}

Na modelovanie geometrie celej vzorky bol použitý softvér AutoCAD, v ktorom bola celá vzorka namodelovaná a následne vo formáte .sat importovaná do softvéru Abaqus. Pri modelovaní celej hmoty boli jednotlivé časti od seba odčítané tak, aby sa objem hmôt navzájom neprekrýval. Výstuž bola namodelovaná ako 2D prvok, prút, ktorému bola v nasledujúcom module priradená plocha a materiál. Z dôvodu anizotropie tohto materiálu bolo pri modelovaní kompozitnej časti vzorky potrebné zadefinovat’ aj lokálne súradnicové osi.

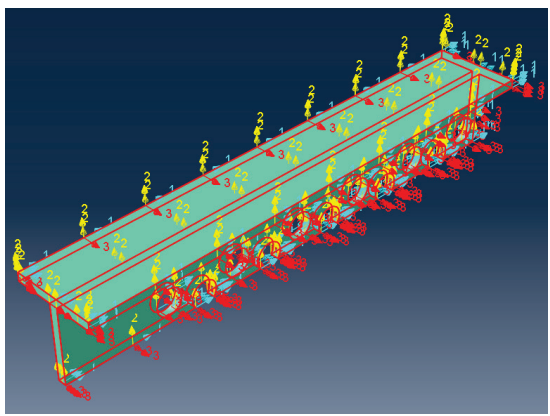

Obr. 4 Čast' vzorky - kompozit a orientácia osí. 


\section{MODUL PROPERTY}

V tomto module boli zadané hodnoty materiálových charakteristík, ktoré boli ziskané experimentálnýmy skúškami v laboratóriu. Následne bol každej časti vzorky priradený materiál a v prípade prútov výstuže aj plocha prierezu. Materiál kompozitného nosníka bol kalibrovaný podl’a výsledkov t’ahovej skúšky, pracovného diagramu, ktorý bol vložený do programovej súčasti Calibrations. Materiálové charakteristiky strednej ocel’ovej časti a výstuže boli definované pomocou hustoty a elastických vlastností.

Materiál kompozitného nosníka je anizotropný v dvoch smeroch, teda ho môžeme považovat' za ortotropný materiál, ktorému bolo potrebné zadat' materiálové charakteristiky vo všetkých smeroch. Na správne zadefinovanie bola použitá elasto-plastická analýza. Pre správne zadefinovanie každého materiálu v 3D MKP analýze je potrebné zadat’ hustotu materiálu. V prípade kompozitného nosníka bola hustota uvažovaná s hodnotou $1,8 \mathrm{~kg} / \mathrm{m}^{3}$.

Na určenie elastického správania materiálu boli použité namerané hodnoty modulov pružnosti v t'ahu a šmyku. Poissonová konštanta nebola nameraná, preto bola použitá hodnota 0,33 . Zadávanie popisuje manuál softvéru pomocou tzv. Engineering Constants a teda E12, E13, E23, nu12, nu13, nu23, G12, G13 a G23.

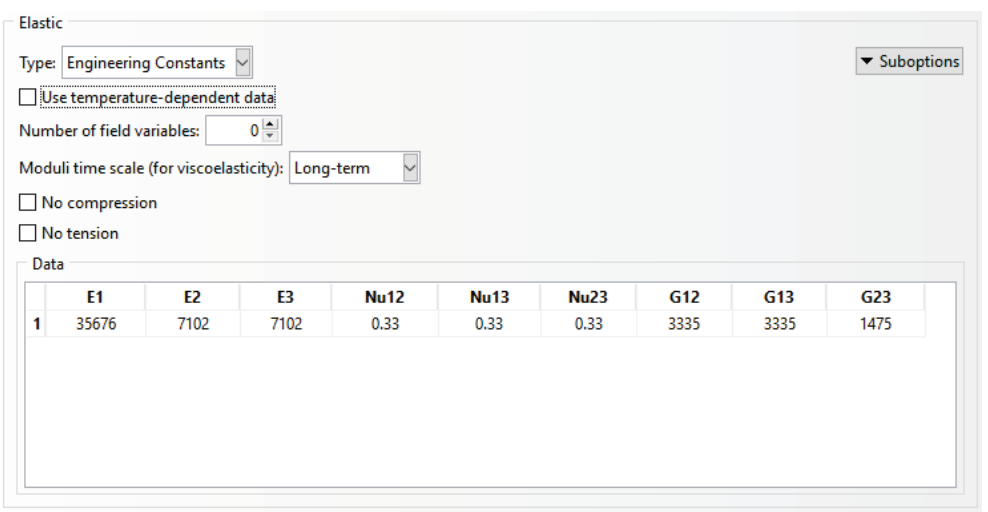

Obr. 5 Elastické materiálové charakteristiky softvéru.

Na určenie plastického správania materiálu bol použitý modul Calibrations, ktorý slúži na zadefinovanie plastických a elastickým materiálov z pracovného diagramu. Na túto kalibráciu boli použité priemerné hodnoty t’ahovej skúšky s vláknami orientovanými v pozdĺžnom smere, v smere 1.

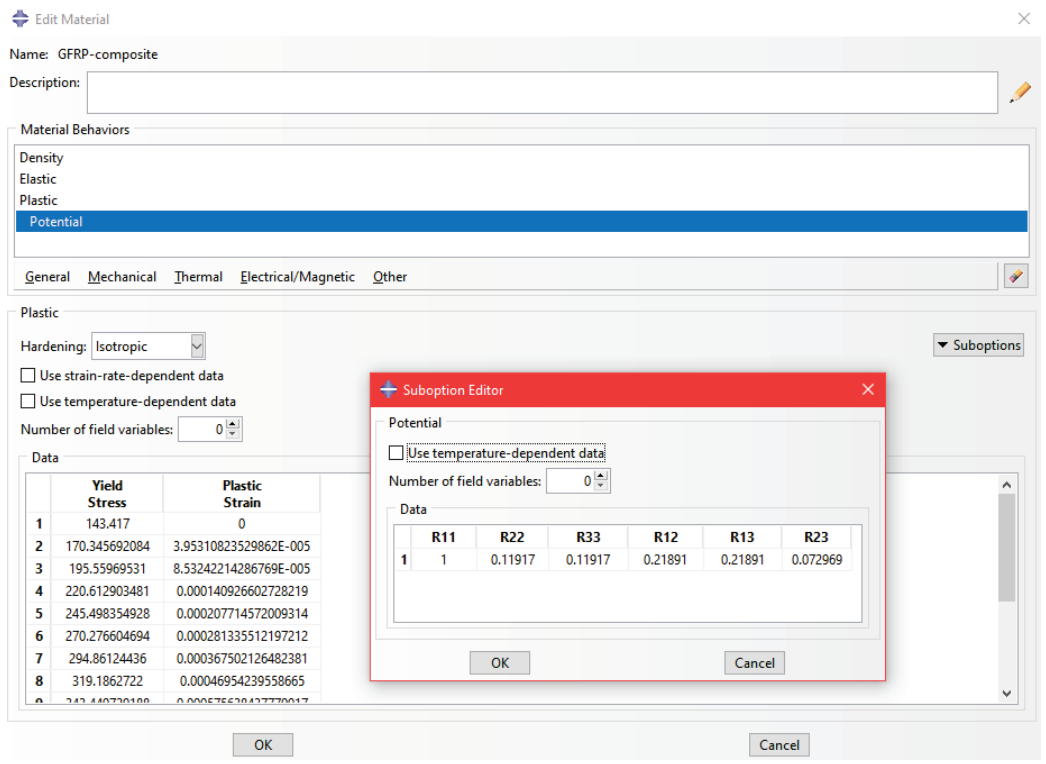

Obr. 6 Plastické materiálové charakteristiky softvéru. 
Na zadefinovanie plastického správania sa anizotropného kompozitného materiálu bol použitý modul Plastic, ktorého súčast'ou je modul Potential. Tento modul funguje podl'a funkcie nazývanej Hill's potential function. Materiálové charakteristiky betónu boli určené v laboratóriu pomocou experimentov. Na zadefinovanie charakteristík betónu bola použitá metóda Concrete Damage Plasticity. Táto metóda spočíva v zadefinovaní materiálových charakteristík betónu pomocou modulov, ktoré ponúka táto metóda a to Plasticity, Compressive Behavior a Tensile Behavior.

\section{MODUL ASSEMBLY}

V tomto module boli spojené jednotlivé časti vzorky do jedného celku, čo je zobrazené na nasledujúcom obrázku. Na obrázku je jedna čast’ betónu skrytá pre lepšiu predstavu geometrie.

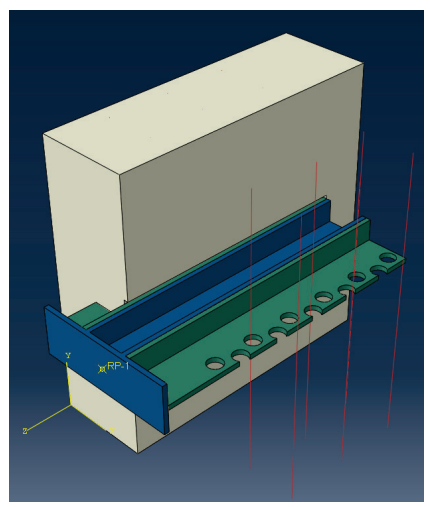

Obr. 7 Vzorka pretláčacej skúšky.

V strede zat’ažovacej plochy je umiestnený referenčný bod, v ktorom je sústredená sila zat’ažovania.

\section{MODUL STEP}

Na výpočet bol použitý nelineárny, explicitný výpočet. Čas kroku bol nastavený na hodnotu 0,1 , čo samotný čas výpočtu znižuje desat'krát, ale hodnota hustoty jednotlivých elementov v sieti je desat'krát zvýšená.

Pri vel'mi malých elementoch niekedy dochádza ku pomalej konvergencii, preto bol nastavený maximálny čas na dosiahnutie konvergencie elementu na 1e-7.

V tomto module sa taktiež určuje počet zápisov, ktorý bol rovný počtu zat'ažovacích cyklov, a taktiež výsledky, ktoré boli očakávané, teda pretvorenie, porušenie betónu, napätia a pomerné pretvorenia.

\section{MODUL INTERACTION}

Kontakt medzi jednotlivými prvkami bol nastavený tak, aby medzi betónom a spriahovacím pásom vznikalo trenie s koeficientom trenia 0,18 . Pre lepšiu konvergenciu elementov a správne zadanie kontaktu bola použitá metóda Penalty contact method, kde je okrem správnych vlastností kontaktu nutné nastavit' nadradenú a podradenú plochu. Ked’že betón má väčšie zastúpenie v celkovom modeli, tak nadradené plochy boli plochy betónu a podradené plochy kompozitu.

Medzi kompozitným prvkom a ocel'ou bol nastavený dokonale tuhý spoj, ktorý bol v skutočnosti zabezpečený skrutkami. V tomto prípade bolo taktiež nutné určit’ nadradenú a podradenú plochu, pričom nadradené boli plochy ocele a podradené plochy kompozitu.

\section{MODUL LOAD}

Okrajové podmienky boli nastavené tak, aby nedochádzalo ku vertikálnemu posunu betónu. Ked’že ide o uloženie, tak je toto nastavenie uvažované ešte pred zat'ažovaním vzorky. 
Zat’aženie bolo nastavené vo vertikálnom smere podl'a zat’ažovacích cyklov jednotlivých skúšaných spriahovacích pásov.
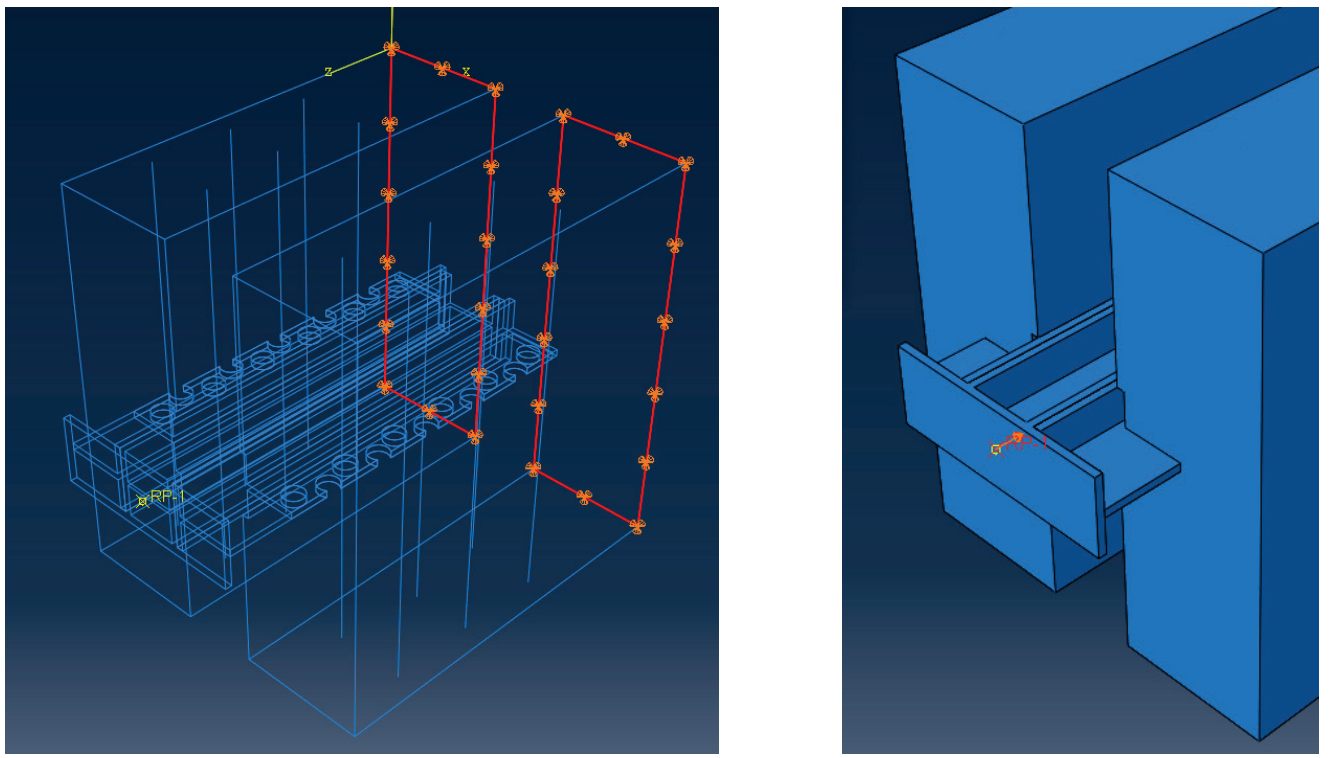

Obr. 8 Okrajové podmienky modelu vzorky.

\section{MODUL MESH}

Pri výpočte pomocou MKP je jednou z najdôležitejších vecí správne nastavenie siete. V analýze pretláčacej skúšky pomocou MKP bola snaha o hexagonálnu 3D siet', čo má jednu zo základných výhod to, že nevznikajú chybné elementy a urýchl'uje to výpočet. Pre komplikovanejšiu geometriu prvkov pretláčacej vzorky bolo nutné časti rozdelit' na jednoduchšie prvky tak, aby bolo možné hexagonálnu 3D siet' elementov vytvorit'. Toto rozdelenie hmoty má vplyv len na elementy, nie na prvok ako taký.

Abaqus ponúka možnost' siete aj v tvare štvorbokého ihlana, čo je metóda, ktorou je možné vytvorit' siet' aj na vel'mi komplikovaných prvkoch bez potreby vytvárania akéhosi delenia. Nevýhodou však je predlžovanie výpočtu a častejší výskyt elementov, ktoré majú problém konvergovat' pri výpočte.
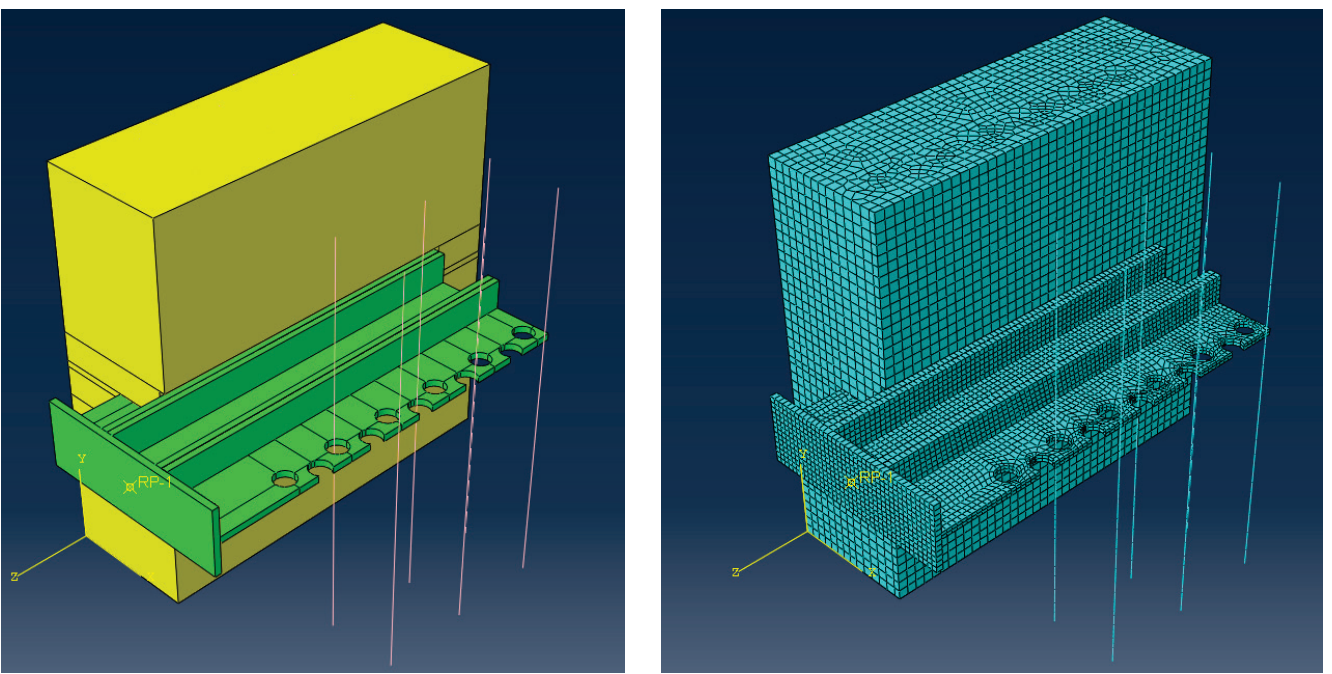

Obr. 9 Siet' 3D modelu před a po spustení siet'ovania. 
Pre rôznu hustotu materiálov hustota elementov bola rozdielna. Pre betón bola použitá hustota elementov 15, pre spriahovací pás, výstuž a ocel'ovú stredovú čast' 8 . Pre jednotlivé časti bolo potrebné nastavit' typ elementov tak, aby správne vystihovali predpoklad 3D správania sa materiálov. Pre výstuž ako 2D prvok bolo nutné nastavit' typ elementu tak, aby sa správali ako 3D elementy a nevznikali kolízie medzi 3D a 2D analýzou.

\section{MODUL JOB}

Na urýchlenie analýzy bolo použitie procesora zvýšené na $100 \%$ a počet použitých logických procesorov na 20 , čo skrátilo výpočet odhadom 2-3 krát.

\section{ZÁVER}

Analýzy pomocou MKP vytvára mnoho otvorených tém. Napríklad zadávanie materiálových charakteristík aj s limitnou hodnotou, kde dôjde ku porušeniu vzorky. Ďalšou témou, ktorá zostáva otvorená, je snaha o zrýchlenie výpočtu a jeho vplyv na výsledky. Otázka siet'ovania a vytvárania elementov v MKP analýze je tiež dôležitou témou, ktorej by tiež bolo vhodné sa venovat'.

\section{Pod'akovanie}

Prezentovaný dokument bol podporený projektom: VEGA 1/0172/20 "Napätová a deformačná analýza nosných prvkov z ocele, skla a kompozitných materiálov”, ktorý podporilo Ministerstvo školstva, vedy, výskumu a športu Slovenskej republiky.

\section{Referencie}

[1] Rewers, Iga. (2019) Numerical Analysis of RC beam with High Strength Steel Reinforcement using CDP model. IOP Conference Series: Materials Science and Engineering. 471. 022025. 10.1088/1757$899 X / 471 / 2 / 022025$.

(PDF) Numerical Analysis of RC beam with High Strength Steel Reinforcement using CDP model (researchgate.net)

[2] Demir, Aydin et al. "EFFECT OF VISCOSITY PARAMETER ON THE NUMERICAL SIMULATION OF REINFORCED CONCRETE DEEP BEAM BEHAVIOR.” (2018). [PDF] EFFECT OF VISCOSITY PARAMETER ON THE NUMERICAL SIMULATION OF REINFORCED CONCRETE DEEP BEAM BEHAVIOR | Semantic Scholar

[3] Hafezolghorani Esfahani, Milad \& Hejazi, Farzad \& Vaghei, Ramin \& Jaafar, Mohd \& Karimzade, Keyhan. (2017). Simplified Damage Plasticity Model for Concrete. Structural Engineering International. 27. 68-78. 10.2749/101686616X1081. (PDF) Simplified Damage Plasticity Model for Concrete (researchgate.net)

[4] ABAQUS Analysis User's Manual, Version 6.6 Documentation ABAQUS Analysis User's Manual (v6.6) (wustl.edu)

[5] IVANČO, V., KUBÍN, K. a KOSTOLNÝ, K. Metóda konečných prvkov I. Košice : Elfa, 1994. ISBN 80967131-4-0. 